\title{
Cyclic voltammetric study on the effect of the introduction of secondary ligands on the redox behaviour of the copper-saccharin complex
}

\author{
Monira Laiju, H.M. Naseem Akhtar, M.A. Mamun, M.d. Abdul Jabbar and M.Q. Ehsan* \\ Department of Chemistry, Faculty of Science, University of Dhaka, Dhaka-1000, Bangladesh.
}

Revised: 25 August 2009 ; Accepted: 16 October 2009

\begin{abstract}
The detailed redox behaviour of copper-saccharin (Cu-sac) complex was examined using the cyclic voltammetric technique. It was found that the adsorption process suppresses the Faradaic process of the $\mathrm{Cu}$-sac complex. The effect of the introduction of secondary ligands such as 1,10-phenanthroline (phen), pyridine (py) and bypyridine (bp) on the redox behaviour of the $\mathrm{Cu}$-sac complex in aqueous solution was studied where these ligands contribute on the charge-transfer kinetics of the complex. The heterogeneous charge transfer rate constants are found to follow the order $\mathrm{Cu}\left(\mathrm{NO}_{3}\right)_{2}>\mathrm{Cu}$-sac-bp $>\mathrm{Cu}$-sac $>$ $\mathrm{Cu}$-sac-phen $>\mathrm{Cu}$-sac-py.
\end{abstract}

Keywords: Copper-saccharin complex, cyclic voltammetry, ligands, redox behaviour.

\section{INTRODUCTION}

Copper is essential for many diverse functions in the biological system such as formation of melanin, electrontransport, phospholipid synthesis, collagen synthesis and integrity of myelin sheath. Three $\mathrm{Cu}$-containing proteins, such as, cerebrocuprein, erythrocuprein and hepatocuprein occur in the brain, blood (RBC) and liver respectively ${ }^{1}$. Many Copper(II)-complexes show biological activity. For example, complexes of $\mathrm{Cu}$ (II) with bioactive carboxyamide ligands $N^{\prime}, N^{\prime \prime}$-bis(3-carboxy-1oxoprop-2-enyl)2-amino- $N$-arylbenzamidine, $N^{\prime}, N^{\prime \prime}$-bis(3carboxy -1-oxopropanyl)2 amino- $N$-arylbenzamidine and $\quad N^{\prime}, N^{\prime \prime}$-bis(3-carboxy-1-oxophenelenyl)2-amino- $N$ arylbenzamidine show bioactivity against the growth of bacteria and pathogenic fungi, and the results indicate that the ligand and its metal complexes possess notable antimicrobial properties ${ }^{2}$.
Saccharin (Sac) is used as a pharmaceutical excipient in the formulation of different medicinal products like syrups, suspensions and as a sweetening agent. It is a good ligand and coordinates through its $\mathrm{N}$ atom. Due mainly to the fact that it can act as biologically active substance and thus affect the living systems, the metal complexes of saccharin have drawn certain scientific attention during the last two decades. X-ray diffraction and Fourier transform infrared (FT-IR) spectroscopic studies on the mixed ligand complex of $\mathrm{Cu}(\mathrm{II})$ with saccharin and pyridine in the solid state have been reported. It has been concluded that $\left[\mathrm{Cu}(\mathrm{II})(\mathrm{sac})_{2}\left(\mathrm{H}_{2} \mathrm{O}\right)_{4}\right]$ complex shows an unusually high lability towards water interchange with aromatic nitrogen bases such as pyridine ${ }^{2}$. Because of their potential pathological effects a study of the structural properties of metal(II) saccharin compounds containing aromatic nitrogen bases as secondary ligands has provoked a pronounced interest recently. The spectroscopic properties of saccharin in metal complexes with pyridine ${ }^{3-4}$, imidazol ${ }^{5-7}, 2,2$ 'bipyridine ${ }^{8}$ and 1,10-phenanthroline ${ }^{9}$ have been reported. No references on the electrochemical behaviour of the mixed ligand complexes of cysteine, $\mathrm{Cu}$ (II)-saccharinate complex and saccharin-cysteine interaction in aqueous medium have been traced so far in the literature.

Due to the diverse uses of the metal-ligandcomplexes, scientists have been trying to improve the performance of metal-ligand complexes. One of the ways to improve the performance of a complex either for its electrochemical and/or-photochemical activities is to introduce a second ligand into the complex. For example, photoluminescence and redox properties of europium complexes increase by introducing 1,10-phenanthroline,

\footnotetext{
*Corresponding author (mqehsan@yahoo.com,mdqehsan@gmail.com)
} 
into the complex ${ }^{10}$. The role of the second ligand is not only to saturate the co-ordination number of the central metal ion but also to improve the volatility and stability of the complex ${ }^{11}$. A Study ${ }^{12}$ reported that carrier-transport characteristics and light-emitting properties can be improved by using bathophenanthroline as the second ligand. This situation lead to the pesent study of the effect of secondary ligand in a complex. In this paper, the following is reported i) the redox behaviour of $\mathrm{Cu}$-system in $\mathrm{Cu}$-saccharin complex, ii) redox behaviour of $\mathrm{Cu}-$ saccharin complex in the presence of secondary ligands such as, 1,10-phenanthroline, 2,2'-bipyridine and pyridine at a glassy carbon electrode in aqueous $\mathrm{KCl}$ solution and acetate buffer solutions of different $\mathrm{pH}$. Among all the voltammetric techniques, cyclic voltammetry $(\mathrm{CV})$ is extremely popular in electrochemical research, because it can provide useful information about redox reactions in an easily interpretable form ${ }^{13}$.

\section{METHODS AND MATERIALS}

Reagents and solutions: All the reagents and solutions were prepared using analar grade chemicals. The ligands used in the synthesis were from BDH, England and E-Merck, Germany. To study $\mathrm{pH}$ effect, solutions of the complexes were prepared using acetate buffer solutions of $\mathrm{pH} 4.1,4.5,4.9,5.2$ and 5.4, respectively. The preparations of acetate buffer solutions of different $\mathrm{pH}$ values were done using sodium acetate (MERCK, Germany) and acetic acid (Sigma-Aldrich)' according to the literature ${ }^{14}$.

Equipment: The current-voltage measurements were performed with an Epsilon electrochemical workstation of Bioanalytical System Inc., (BAS), USA. The pH meter (Orion, Thermo Electron Corporation) was used to measure the $\mathrm{pH}$ of experimental solutions. A voltammetric cell (three-electrode cylindrical shape micro-cell system) made of borosilicate glass was used in this work. Glassy carbon electrode (GCE) with geometric area $0.05 \mathrm{~cm}^{2}$ was used as the working electrode, $\mathrm{Ag} / \mathrm{AgCl}$ (saturated $\mathrm{KCl}$ ) as the reference electrode and platinum wire as the counter electrode. All the electrodes were procured from BAS, USA. The mixing and purging of $\mathrm{N}_{2}$ gas $(99.97 \%$ pure, procured from Bangladesh Oxygen Limited) were done by using a BAS C-3 Cell stand combined with a Faraday Cage and a magnetic stirrer. All of the potentials reported in this paper are with respect to $\mathrm{Ag} / \mathrm{AgCl} / \mathrm{KCl}$ electrode.

Preparation of the electrode surface: Prior to use, the glassy carbon electrode surface was polished with $0.5 \pi$ fine alumina powder slurry in deionized water on a polishing cloth. After polishing, the electrode was rinsed with a continuous flow of deionized water and wipedoff with a clean tissue paper to remove the last drop of water. The reference and the counter electrodes were also thoroughly rinsed with deionized water prior to use.

Preparation of the complexes: Copper-saccharin $(\mathrm{Cu}-$ sac), copper-sac-phenanthroline (Cu-sac-phen), coppersaccharin-bipyridine (Cu-sac-bpy) and copper-saccharinpyridine (Cu-sac-py) complexes were synthesized and characterized following published procedures ${ }^{15,16}$.

Details of the cyclic voltammetric study of different systems: The redox behaviour of $200 \mathrm{ppm}$ solutions of copper complexes were studied in $0.1 \mathrm{M} \mathrm{KCl}$ at room temperature using cyclic voltammetric technique at a glassy carbon electrode. The effect of co-ordination was described by comparing the cyclic voltammograms (CVs) between un-coordinated copper and various copper-ligand complexes. The effect of presence of the secondary ligands, such as, 1,10-phenanthroline, 2.2'bipyridine and pyridine, respectively, were also studied.

The redox properties of the corresponding complexes in aqueous $\mathrm{KCl}$ and acetate buffer were studied by comparing with that of pure $\mathrm{Cu}$ (II) and the $\mathrm{Cu}$-sac complex.

\section{RESULTS AND DISCUSSION}

\section{Redox behaviour of $\mathrm{Cu}(\mathrm{II})$ in $\mathrm{Cu}$-sac complex}

The redox behaviour of $\mathrm{Cu}$ (II) in cu-sac complex was studied at a glassy carbon electrode within the potential window of 1500 to $-1000 \mathrm{mV}$ at room temperature by comparing the cyclic voltammograms of $\mathrm{Cu}$ (II) in $\mathrm{Cu}\left(\mathrm{NO}_{3}\right)_{2}$. CV of 200 ppm $\mathrm{Cu}$ and 200 ppm $\mathrm{Cu}-\mathrm{sac}$ complex in $0.1 \mathrm{~mol} \mathrm{dm}^{-3} \mathrm{KCl}$ are shown in curve '(a)' and '(b)' respectively in Figure1(A).

Compared to the pure metal salt [curve (a)] of $\mathrm{Cu}(\mathrm{II})$, the peak positions and the peak currents in the $\mathrm{Cu}$-sac complex [curve (b)] are drastically changed. The reversible peak pair of pure $\mathrm{Cu}$ (II) [curve (a)] in aqueous $\mathrm{KCl}$ solution observed at $0.480 \mathrm{~V}$ and $0.420 \mathrm{~V}$ respectively, is shifted to more cathodic region in the case of Cu-sac complex [curve (b)]. The two anodic peaks of $\mathrm{Cu}$-sac complex were found at potentials $0.178 \mathrm{~V}$ and $-0.007 \mathrm{~V}$ respectively, compared to those in case of pure copper in aqueous solution. In the case of $\mathrm{Cu}-\mathrm{sac}$ complex, the anodic peaks become closer to each other. 
The electrode reactions for pure $\mathrm{Cu}$ (II) may be shown according to the following scheme:

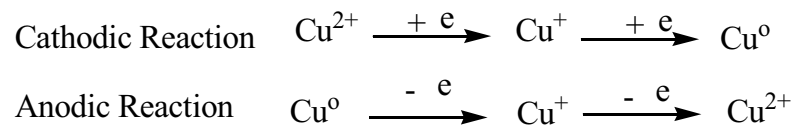

The redox behaviour of the $\mathrm{Cu}$-sac complex in aqueous $\mathrm{KCl}$ solution, $\mathrm{CV}$ of $\mathrm{Cu}$-sac complex has been performed at different scan rates and represented in Figure 1(B). The current-potential data and calculated parameters for the $\mathrm{Cu}$-sac complex derived from Figure 1(B) are listed in Table 1. It shows that the first cathodic peak becomes sharper and the second one becomes broader with higher scan rate. For the first cathodic peak, there is no change in peak position, and the second cathodic peak shifts towards negative potential. For the anodic peak, the first one is shifted towards more positive potential and the second peak shows no change. Interestingly, the second cathodic peak at $c a$. $-0.45 \mathrm{~V}$ peak has broadened in the case of $\mathrm{Cu}$-sac complex with increase in scan rate and the

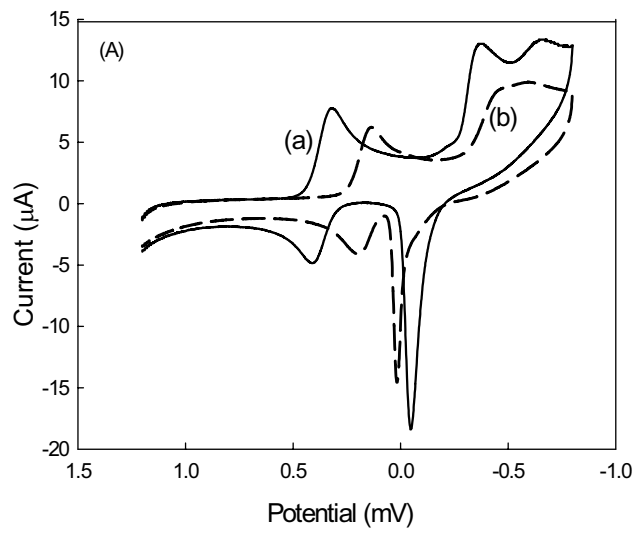

peak current is reduced at least two fold as compared to the pure $\mathrm{Cu}(\mathrm{II})$ [Figure 1(B)]. This may be due to some other process occurring simultaneously at the electrode surface. Such behaviour has been ascribed to slower charge propagation, probably due to the difference in solvation and or permeability ${ }^{17}$. The chemical reactions, which occur in this process, may follow the electron transfer process ${ }^{18}$. Therefore, the mass transfer process is limited due to the charge transfer kinetics ${ }^{19}$ indicating that the peak current increases and the ratio of the peak current $\left(\mathrm{i}_{\mathrm{pa}} / \mathrm{i}_{\mathrm{pc}}\right)$ decreases with the increase of scan rate. The second cathodic process, where the peak has broadened, is probably influenced by the redox behaviour of the first redox process (quasi-reversible) ${ }^{20}$ occurring at the positive side in the CV. This also causes the redox process to become quasi-reversible as compared to the pure $\mathrm{Cu}$ (II) system, where the same peak-pair is reversible ${ }^{20}$. Figure 2 shows that the peak currents $\left(\mathrm{i}_{\mathrm{p}}\right)$ for both the cathodic and anodic peaks for the $\mathrm{Cu}$-sac complex increase linearly with the square root of the scan rates.

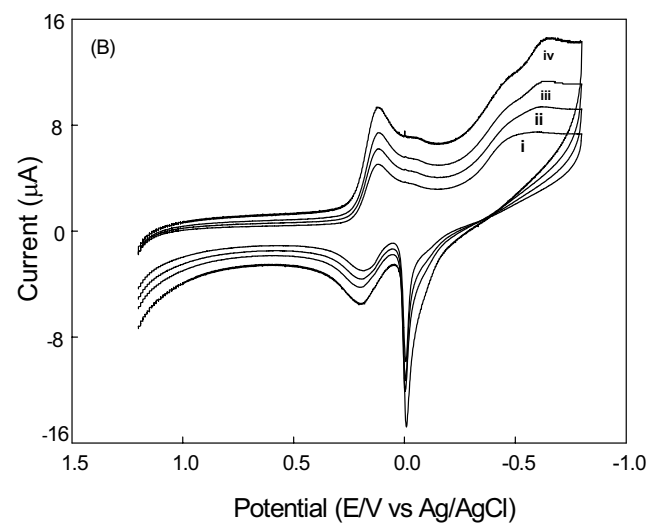

Figure 1: (A) Combined cyclic voltammograms of (a) $200 \mathrm{ppm} \mathrm{Cu(II)-nitrate} \mathrm{and} \mathrm{(b)} 200$ ppm Cu-sac-complex at scan rate $100 \mathrm{mV} \mathrm{s}^{-1}$ and (B) Cyclic voltammograms of Cu-sac-complex (200 ppm) at different scan rates i) 50 , ii) 100 , iii) 150 , iv) 200 and v) $300 \mathrm{mVs}^{-1}$ in $0.1 \mathrm{moldm}^{-3} \mathrm{KCl} \mathrm{vs.} \mathrm{Ag} / \mathrm{AgCl}$

Table 1: Current-potential data, peak separation and peak current ratio of the voltammograms of $200 \mathrm{ppm}$ copper- saccharin complex in $0.1 \mathrm{M}$ $\mathrm{KCl}$ at different scan rates

\begin{tabular}{|c|c|c|c|c|c|c|c|c|c|c|c|c|}
\hline $\begin{array}{l}\text { (v) } \\
\mathrm{V} / \mathrm{sec}\end{array}$ & $\begin{array}{l}\mathrm{Ep}_{\mathrm{a} 1} \\
\mathrm{~V}\end{array}$ & $\begin{array}{c}\mathrm{Ep}_{\mathrm{a} 2} \\
\mathrm{~V}\end{array}$ & $\begin{array}{c}\mathrm{Ep}_{\mathrm{c} 1} \\
\mathrm{~V}\end{array}$ & $\begin{array}{c}-\mathrm{Ep}_{\mathrm{c} 2} \\
\mathrm{~V}\end{array}$ & $\begin{array}{r}-\mathrm{ip}_{\mathrm{a} 1} \\
\mathrm{~mA}\end{array}$ & $\begin{array}{r}-\mathrm{ip}_{\mathrm{a} 2} \\
\mathrm{~mA} \\
\end{array}$ & $\begin{array}{l}\mathrm{ip}_{\mathrm{c} 1} \\
\mathrm{~mA}\end{array}$ & $\begin{array}{l}\mathrm{ip}_{\mathrm{c} 2} \\
\mathrm{~mA}\end{array}$ & $\begin{array}{l}\Delta \mathrm{E}_{\mathrm{p} 1} \\
\mathrm{~V}\end{array}$ & $\begin{array}{l}\Delta \mathrm{E}_{\mathrm{p} 2} \\
\mathrm{~V}\end{array}$ & $\begin{array}{l}\mathrm{ip}_{\mathrm{al} 1} \\
\mathrm{ip}_{\mathrm{c} 1}\end{array}$ & $\begin{array}{l}\mathrm{ip}_{\mathrm{a} 2} / \\
\mathrm{ip}_{\mathrm{c} 2}\end{array}$ \\
\hline 0.050 & 0.162 & 0.020 & 0.124 & 0.574 & 2.979 & 8.01 & 3.766 & 5.229 & 0.038 & 0.596 & 0.791 & 1.532 \\
\hline 0.100 & 0.178 & 0.017 & 0.118 & 0.597 & 2.102 & 12.09 & 4.907 & 8.257 & 0.060 & 0.614 & 0.429 & 1.464 \\
\hline 0.150 & 0.195 & 0.019 & 0.113 & 0.614 & 2.453 & 13.32 & 5.783 & 9.771 & 0.082 & 0.633 & 0.424 & 1.363 \\
\hline 0.200 & 0.195 & 0.019 & 0.113 & 0.614 & 2.453 & 14.03 & 7.009 & 11.66 & 0.082 & 0.633 & 0.350 & 1.203 \\
\hline 0.300 & 0.195 & 0.017 & 0.118 & 0.641 & 3.154 & 15.64 & 8.411 & 14.79 & 1.352 & 0.631 & 0.375 & 1.058 \\
\hline
\end{tabular}

$v=$ scan rate, $\mathrm{Ep}_{\mathrm{a} 1}=$ anodic peak potential for the $1^{\text {st }}$ peak, $\mathrm{Ep}_{\mathrm{a} 2}=$ anodic peak potential for the $2^{\text {nd }}$ peak, $\mathrm{E} \mathrm{p}_{\mathrm{c} 1}=$ cathodic peak potential for the $1^{\text {st }}$ peak, $\mathrm{Ep}_{\mathrm{c} 2}=$ cathodic peak potential for the $2^{\text {nd }}$ peak, $\mathrm{ip}_{\mathrm{a} 1}=$ anodic peak current for the $1^{\text {st }}$ peak, $\mathrm{ip}_{\mathrm{a} 2}=$ anodic peak current for the $2^{\text {nd }}$ peak, $\mathrm{ip}_{\mathrm{c} 1}=$ cathodic peak current for the $1^{\text {st }}$ peak, $\mathrm{ip}_{\mathrm{c} 2}=$ cathodic peak current for the $2^{\text {nd }}$ peak, $\mathrm{DE} \mathrm{p}_{\mathrm{p}}=$ peak separation for the $1^{\text {st }}$ pair, $\mathrm{DE}_{\mathrm{p} 2}=$ peak separation for the $2^{\text {nd }}$ pair. 
Though the peak currents vary linearly, the intercepts for both the lines at the Y-axis indicate that the process is adsorption controlled ${ }^{21}$. Figure 3 indicates that with increasing scan rate peak potential separation $\left(\Delta \mathrm{E}_{\mathrm{p}}\right)$ also increases. This may be due to the slow electron transfer kinetics or Ohomic Potential (iR) drop ${ }^{22}$.

Effect of $\mathrm{pH}$ : The $\mathrm{CV}$ of the $\mathrm{Cu}$-sac complex was studied at different $\mathrm{pH}$ values $(4.1,4.5,4.9,5.2$ and 5.4) using the acetate buffer. In the acetate buffer, we observe significant change in the $\mathrm{CV}$ of the $\mathrm{Cu}$-sac complex. At $\mathrm{pH} 4.1$, two significant cathodic peaks can be seen but the anodic peaks merge to give one peak. At higher $\mathrm{pH}$ (pH 5.4), the cathodic peaks become significantly sharp and anodic peak splits.

Concentration effect: $\mathrm{CVs}$ of $\mathrm{Cu}$-sac complex of various concentrations $(150,200$, and $300 \mathrm{ppm})$ were studied, which shows that the cathodic peak current increases linearly with increase in concentration as it is expected from the diffusion controlled process ${ }^{21}$. In this experiment, it is also observed that the linear line

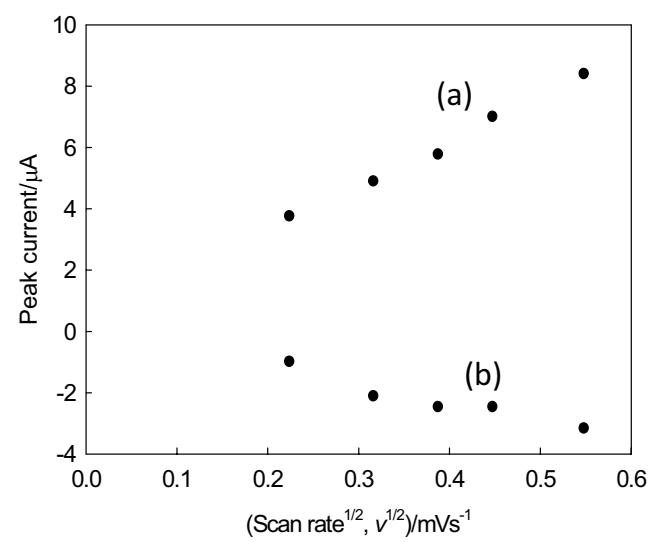

Figure 2: Variation of peak current with square root of scan rate for $\mathrm{Cu}$-sac complex for (a) anodic and (b) cathodic peak currents

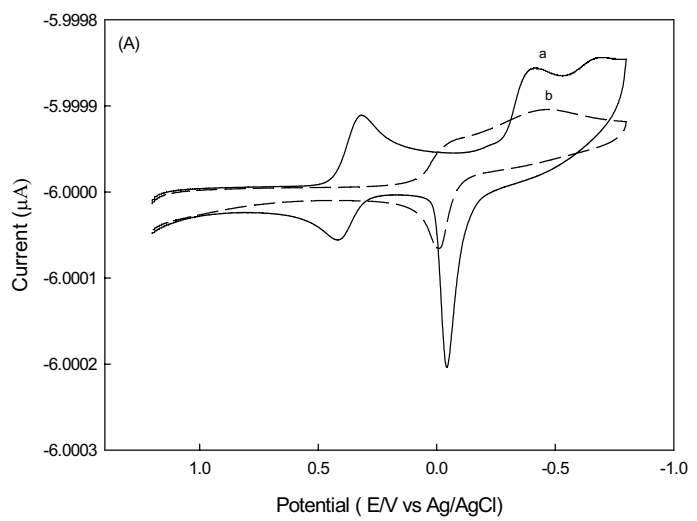

does not pass through the origin (figure not shown) as it is expected from the Randless-Sevcik equation. This strongly suggests that the electrogenerated cathodic species generated from the reduction of $\mathrm{Cu}$-sac complex are adsorbed on the electrode surface. Therefore, the $\mathrm{Cu}$ sac system in aqueous $\mathrm{KCl}$ electrolytic system is limited by an adsorption controlled process ${ }^{21}$.

\section{$\mathrm{Cu}$ (II)-saccharin-phenanthroline(Cu-sac-phen) complex}

A $\mathrm{CV}$ of the pure copper $\mathrm{Cu}(\mathrm{II})$ and $\mathrm{Cu}$-sac-phen complex in aqueous $\mathrm{KCl}$ solution at scan rate $100 \mathrm{mVs}^{-1}$ is shown in Figure 4A. The presence of the secondary ligand, phenanthroline has brought about changes in the number of the peaks as well as the shapes of the peaks of the $\mathrm{Cu}$-sac complex.

The $\mathrm{Cu}$-sac-phen complex shows that there are two peaks in the cathodic scan [Figure 4(A), curve b]. The first one is observed as a hump and the second one as a broadened. Peak observed ca. $-0.500 \mathrm{~V}$ vs. $\mathrm{Ag} / \mathrm{AgCl}$.

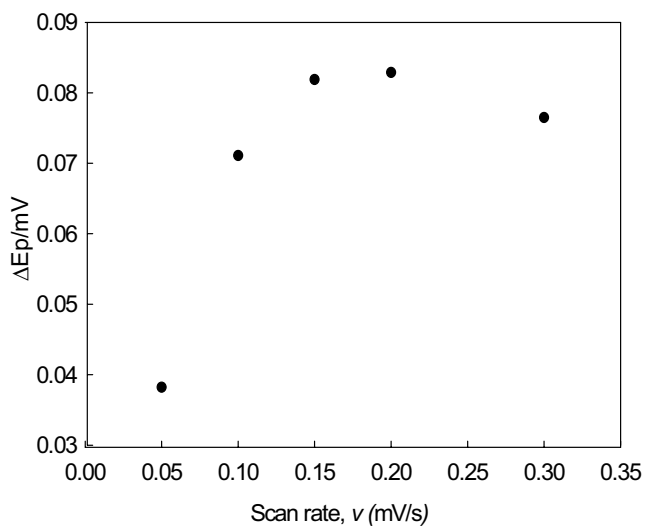

Figure 3: Variation of peak potential separation against scan rate for $\mathrm{Cu}$-sac complex (200 ppm solution) in $0.1 \mathrm{M} \mathrm{KCl}$

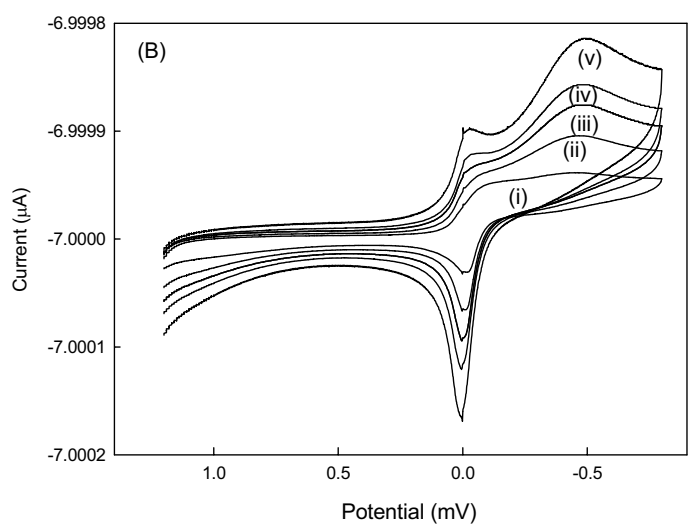

Figure 4: (A) Combined cyclic voltammograms of (a) 200 ppm Cu(II)-nitrate and (b) 200 ppm Cu-sac-phen complex at scan rate $100 \mathrm{mV} \mathrm{s}^{-1}$ and (B) Cyclic voltammograms of Cu-sac-phen complex (200 ppm) at different scan rate: i) 50 , ii) 100 , iii) 150 and iv) $200 \mathrm{mVs}^{-1}$ in $0.1 \mathrm{M} \mathrm{KCl}$ 
With the increase in scan rate, the first cathodic peak becomes sharp and the second cathodic peak becomes an individual. Peak [(Figure 4(B)]. The redox behaviour of both the cathodic processes become prominent with increase in the scan rate. The peak potential separation $\left(\Delta \mathrm{E}_{\mathrm{p}}\right)$ increases slowly with increase in scan rate due to the prominent charge transfer kinetic controlled process. It is also attributed that the Faradaic process is limited in this case $\mathrm{e}^{19}$. The plot of peak current (both the anodic and cathodic peak current) vs. square root of the scan rate are linear at the higher scan rate but deviates from linearity at the slower scan rate( figure not shown). This fact may be explained that at a higher scan rate the process is diffusion controlled and at a slower scan rate there is a contribution of both Nernstian and kinetic controlled processes at the electrode surface. It may also be deduced from the observation that the attachment of the ligand 1,10-phenanthroline to $\mathrm{Cu}$-sac complex makes the system (Cu-sac-phen) bulky, as a result the redox behaviour becomes more prominent at the higher scan rate.

\section{$\mathrm{Cu}$ (II)-saccharin-bipyridine (Cu-sac-bp) complex}

Comparative $\mathrm{CVs}$ between the $\mathrm{Cu}$-sac-bp system (curve b) and pure $\mathrm{Cu}(\mathrm{II})$ (curve a) at scan rate $100 \mathrm{mVs}^{-1}$ are shown in Figure 5(A). The CV of Cu-sac-bp system [curve $\mathrm{b}$ in Figure 5(A)] shows one cathodic and one anodic peak. The peak-pair shows one-step process and exhibit reversible redox behaviour. Interestingly, the first cathodic peak of pure $\mathrm{Cu}$ (II) completely vanishes and the second cathodic peak shifts towards the anodic direction in the case of $\mathrm{Cu}$-sac-bp complex. The shifting of the potential of the cathodic peak towards the positive direction suggests that the reduction process of $\mathrm{Cu}$-sac-bp mixed ligand complex is catalytic-controlled ${ }^{20}$. It is found that the redox behaviour is enhanced for the $\mathrm{Cu}$-sac complex with the introduction of secondary ligand $\mathrm{bp}$. Figure 5(B) represents the $\mathrm{CV}$ of the $\mathrm{Cu}-\mathrm{sac}-\mathrm{bp}$ complex at different scan rates, where it is observed that the cathodic peaks shift to more negative potential and the anodic peaks slightly towards positive potential by increasing the scan rates. The peak currents also increase with increase in scan rates but the cathodic peak becomes broader. The respective cathodic to anodic peak potential separation $(\Delta \mathrm{Ep})$ and peak current ratio also increases with increasing scan rates. Such phenomena have taken place in the case of diffusion process proceeding with a secondary process such as adsorption or other chemical process $^{22}$. The current function $\left(\mathrm{i}_{\mathrm{p}} / \mathrm{v}^{1 / 2}\right)$ for the second cathodic process has also been found to increase with increasing scan rates. A significant increase in the current functions at faster scan rates is a strong indication of the presence of weak adsorption ${ }^{23}$.

\section{Copper-saccharin-pyridine (Cu-sac-py) complex}

Comparative $\mathrm{CVs}$ of pure $\mathrm{Cu}$ (II) (curve a) and $\mathrm{Cu}$-sacpy complex (curve b) are represented in Figure 6(A) at $100 \mathrm{mV} / \mathrm{s}$ scan rate. The first cathodic peak shift towards the anodic direction indicates that the second ligand py catalyzed the first reduction process. However, the second cathodic peak has appeared as a broad peak indicating that the process is adsorption controlled. Thus, the system shows almost the same type of redox behaviour of the $\mathrm{Cu}$-sac complex with a difference in the magnitude of the peak potential due to the presence of the secondary ligand, pyridine. The similar nature of $\mathrm{CVs}$ between $\mathrm{Cu}$-sac and $\mathrm{Cu}$-sac-py complexes suggests that the secondary ligand pyridine has a very small effect (relative to the other mixed ligand complexes of $\mathrm{Cu}-\mathrm{sac}$ complex system) on their redox behaviour. The CVs of the complex at different scan rates have been presented in Figure 6(B), which show changes in peak current but no change in peak position with increasing scan rates.

Table 2: Current-potential data, Tafel slope b, diffusion coefficient, D and the chargetransfer rate constant, $\mathrm{k}_{\mathrm{f}}$ calculated from the voltammograms of $1.0 \mathrm{mM}$ metal salt and metal complexes in $0.1 \mathrm{M} \mathrm{KCl}$ at $100 \mathrm{mV} \mathrm{s}^{-1}$ and at ambient temperature

\begin{tabular}{llllll}
\hline Sample ID & $\begin{array}{l}\mathrm{E}_{\mathrm{pc}} \\
\mathrm{V}\end{array}$ & $\begin{array}{l}\mathrm{i}_{\mathrm{pc}} \\
\mu \mathrm{A}\end{array}$ & $\mathrm{b}$ & $\begin{array}{l}\mathrm{D} \times 10^{11} \\
\mathrm{~cm}^{-2} \mathrm{~s}^{-1}\end{array}$ & $\begin{array}{l}\mathrm{k}_{f} \times 10^{6} \\
\left(\mathrm{~cm} \mathrm{~s}_{-1}\right)\end{array}$ \\
\hline $\mathrm{Cu}\left(\mathrm{NO}_{3}\right)_{2}$ & 0.174 & 13.980 & 0.077 & 0.280 & 3.15 \\
$\mathrm{Cu}$-sac & 0.134 & 5.170 & 0.041 & 0.020 & 1.17 \\
$\mathrm{Cu}$-sac-phen & -0.029 & 3.590 & 0.038 & 0.009 & 0.80 \\
$\mathrm{Cu}-$-sac-bp & -0.177 & 6.870 & 0.2076 & 0.180 & 1.55 \\
$\mathrm{Cu}$-sac-py & 0.134 & 3.010 & 0.0413 & 0.007 & 0.68 \\
\hline
\end{tabular}

$\mathrm{E}_{\mathrm{pc}}=$ cathodic peak potential, $\mathrm{i}_{\mathrm{pc}}=$ cathodic peak current, $\mathrm{b}=$ Tafel slope $=(2.303 \mathrm{RT} /$ $\left.\alpha \mathrm{N}_{\mathrm{a}} \mathrm{F}\right), \mathrm{T}=298 \mathrm{~K}, \mathrm{D}=$ diffusion coefficient, $\mathrm{n}=$ number of electron transferred $=2$, $\mathrm{R}=8.314 \mathrm{~J} \mathrm{~K}_{-1} \mathrm{~mol}_{-1}, \mathrm{~F}=96500 \mathrm{C}, \mathrm{A}=$ surface area of the electrode $=0.05 \mathrm{~cm}^{2}$, $\mathrm{kf}=$ heterogeneous electron transfer rate constant 

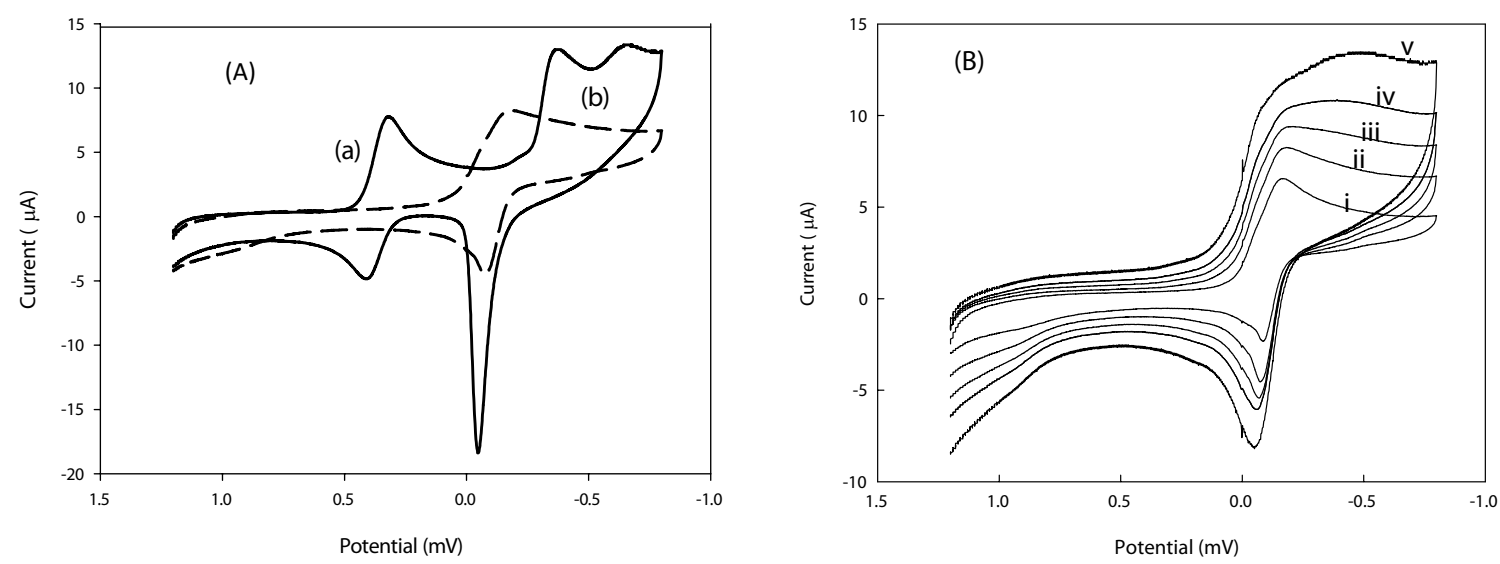

Figure 5: (A) Combined cyclic voltammograms of (a) $200 \mathrm{ppm} \mathrm{Cu(II)-nitrate} \mathrm{and} \mathrm{(b)} 200 \mathrm{ppm} \mathrm{Cu}$-sac-bp complex at scan rate $100 \mathrm{mV} \mathrm{s}^{-1}$ and (B) cyclic voltammograms of Cu-sac-bpy complex (200 ppm) at different scan rates i) 50 , ii) 100 , iii) 150 , iv) 200 and v) $300 \mathrm{mVs}^{-1}$ in $0.1 \mathrm{M} \mathrm{KCl} \mathrm{vs.} \mathrm{Ag} / \mathrm{AgCl}$
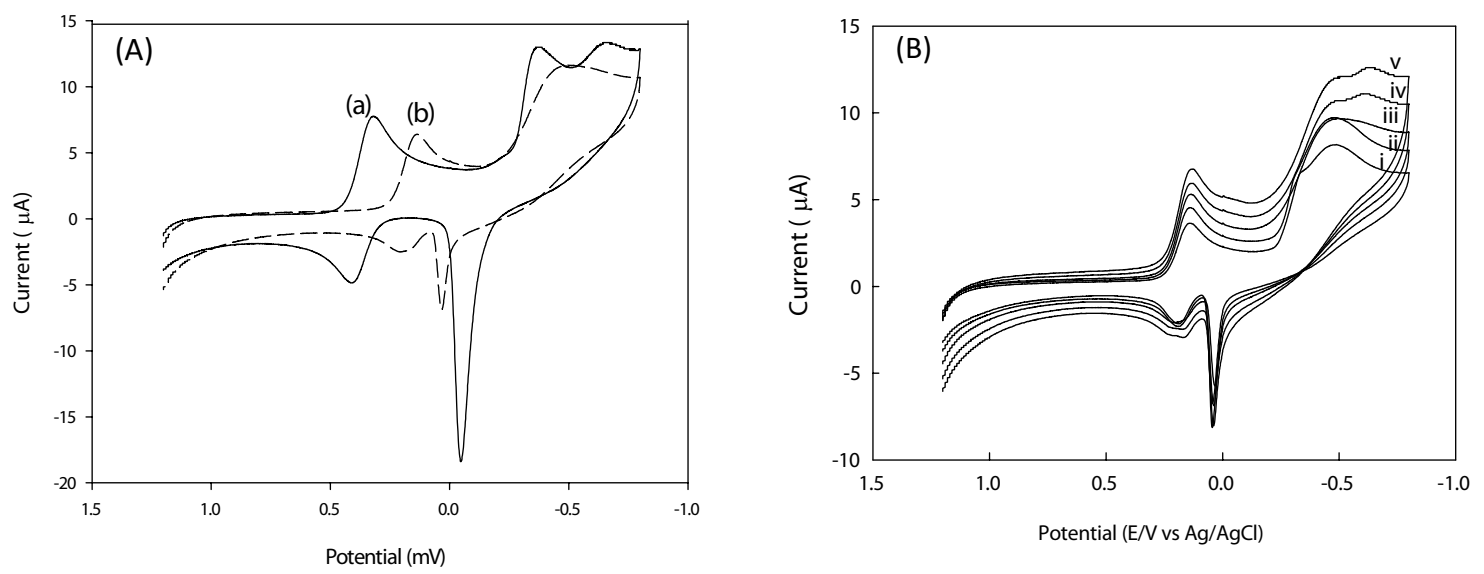

Figure 6(A): Combined CVs of (a) 200 ppm Cu(II)-nitrate and (b) 200 ppm Cu-sac-py complex at scan rate $100 \mathrm{mV} \mathrm{s}^{-1}$ and (B) Cu-sac-py complex (200 ppm) at different scan rates: i) 50, ii) 100, iii) 150 , iv) 200 and v) $300 \mathrm{mVs}^{-1}$ in the supporting electrolyte $(0.1 \mathrm{M} \mathrm{KCl}) \mathrm{vs} . \mathrm{Ag} / \mathrm{AgCl}$

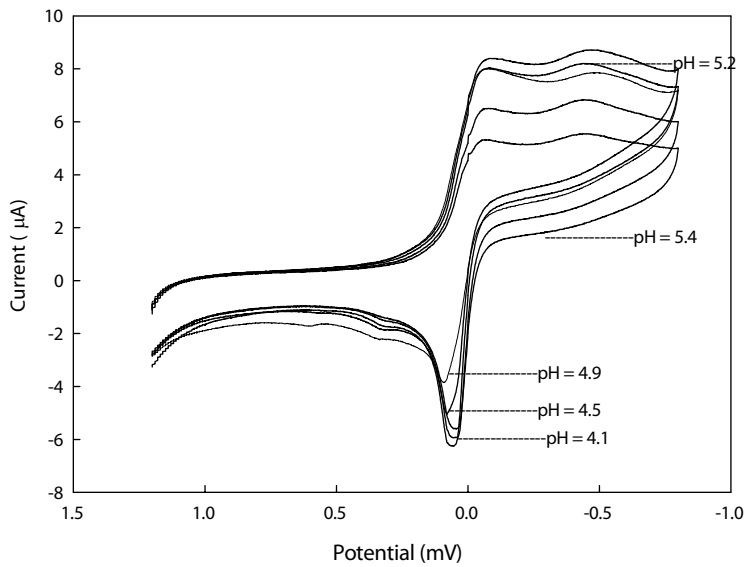

Figure 7: Cyclic voltammograms of Cu-sac-phen (200 ppm solution) complex in acetate buffer at different $\mathrm{pH} 4.1,4.5,4.9,5.2$ and 5.4

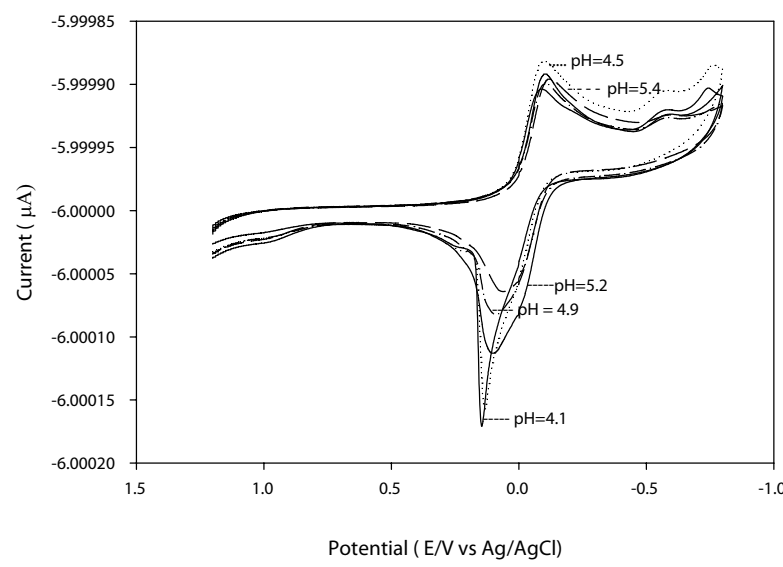

Figure 8: Cyclic voltammograms of Cu-sac-bp (200 ppm solution) complex in acetate buffer at different $\mathrm{pH}$ 

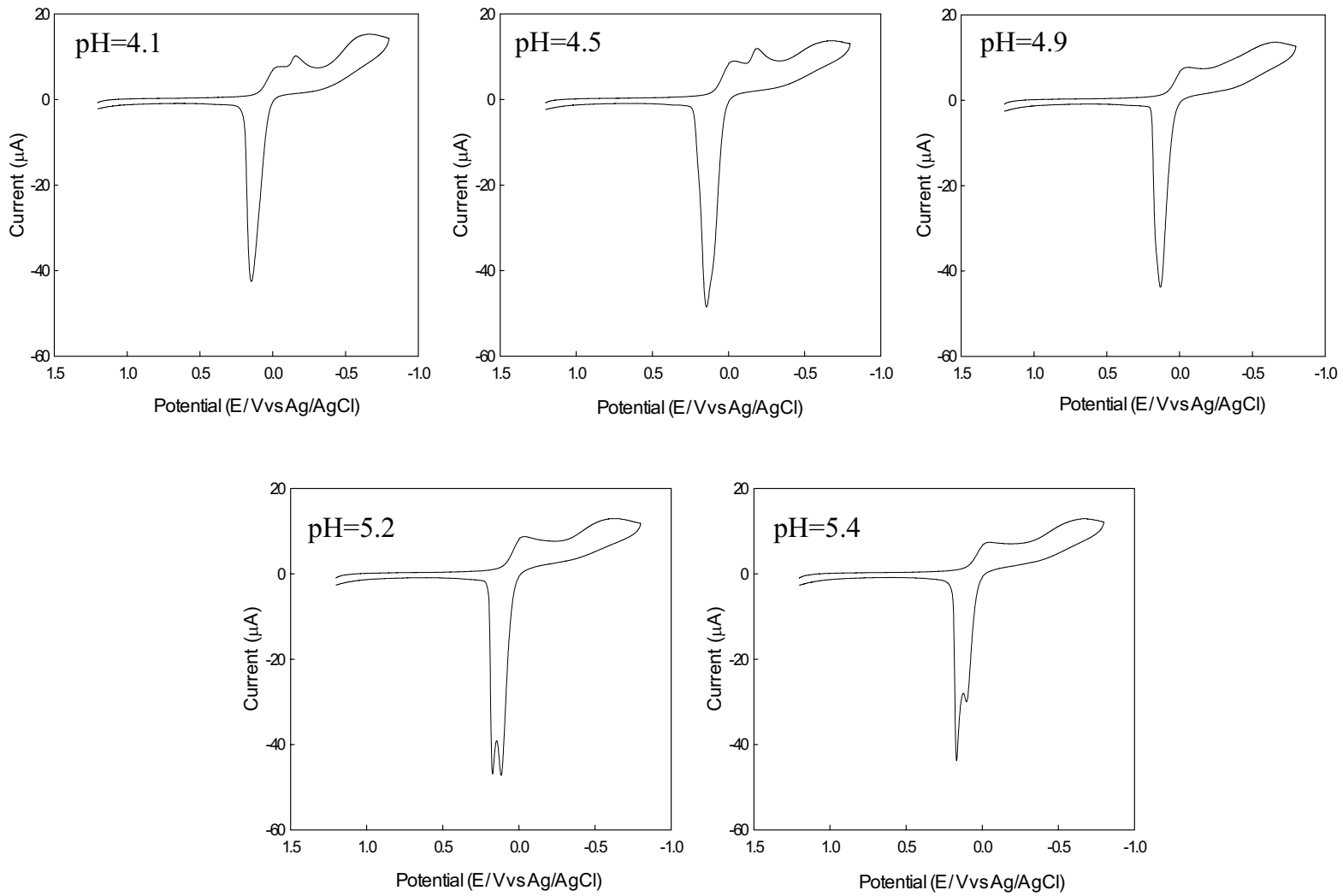

Figure 9: Cyclic voltammograms of Cu-sac-py (200 ppm solution) complex in acetate buffer of different $\mathrm{pH}(4.1,4.5,4.9,5.2$ and 5.4)

\section{Effect of pH}

$\mathrm{CVs}$ of $\mathrm{Cu}(\mathrm{II})$-sac-phen complex at different $\mathrm{pH}$ values are represented in Figure 7. The CVs show that there are small differences in the peak shapes. As it is expected, the anodic peak potentials are shifted to a more anodic position with increase in $\mathrm{pH}$. With one-unit of $\mathrm{pH}$ deviation, the peak potential is shifted to about $60 \mathrm{mV}$, suggesting the involvement of one-electron in the redox reaction ${ }^{24}$.

The CVs of $\mathrm{Cu}$-sac-bp complex, at scan rate $100 \mathrm{mV} \mathrm{s}^{-1}$ in acetate buffer solution at different $\mathrm{pH}$ values are shown in Figure 8.

There are only small differences in the CVs consisting of mainly one pair of cathodic and anodic peaks. The anodic peak becomes broader and the peak current decreases with increase in $\mathrm{pH}$ values. A small peak at $-0.50 \mathrm{~V}$ is due the presence of small amount of oxygen in the medium despite the removal of oxygen by nitrogen purging. Sonicating the GCE surface for the removal of oxygen was avoided, which sometimes disconnect the carbon disc and the copper rod of the electrode. An interesting feature of the $\mathrm{CV}$ of $\mathrm{Cu}$-sac-bp system is the shifting of potential and decreasing the peak current magnitude. It has been noticed that by increasing $\mathrm{pH}$ by a factor of 1 (from $\mathrm{pH} 4.1$ to 5.2), the peak potential shifted about $0.060 \mathrm{~V}$ towards the cathodic position. This suggests that the catalytic activity of $\mathrm{Cu}$-sac complex increases by introducing the second ligand bp and only one-electron is involved in the redox process ${ }^{19,24}$.

$\mathrm{CVs}$ for $\mathrm{Cu}$-sac-py complex at scan rate $100 \mathrm{mVs}^{-1}$ using the acetate buffer are presented in Figure 9. CVs at 4.1 and 4.5 have two cathodic peaks and one anodic peak, whereas at $\mathrm{pH} 5.2$ and 5.4 the trend is the opposite. At $\mathrm{pH} 4.9$, there is only one pair of peaks, i.e. with increase of $\mathrm{pH}$, separation of cathodic peaks decreases and ultimately fuse to one and the peak separation of anodic peak increases and ultimately split into two anodic peaks.

Concentration effect: The CV for all three mixed ligand complexes were also analyzed for different concentrations of solutions (150 ppm, $200 \mathrm{ppm}$ and 300 $\mathrm{ppm})$. In all cases the peak current increases due to the increased concentration of metal ion. Plot of current vs. 
concentration for both cathodic and anodic peak current show a linear nature, indicating that the redox process of copper system in all the complexes is diffusion controlled $^{18}$.

Charge transfer rate constant: The heterogeneous charge transfer rate constants for the copper salt and the copper complexes were calculated. To calculate the heterogeneous charge transfer rate constant, $k_{f}$, the current-potential data obtained from the cyclic voltammograms of metal salts and metal complexes at $100 \mathrm{mV} \mathrm{s}^{-1}$ and $200 \mathrm{mV} \mathrm{s}^{-1}$ were used. The current-potential data, Tafel slope, diffusion coefficient and charge transfer rate constants at room temperature for metal salt and metal complexes are listed in Table 2.

The results in Table 2 illustrates that the $k_{f}$ valuves for all the copper complexes are lower than that of the copper under the same experimental conditions. This may be due to the formation of complexes of copper with the ligands. The $k_{f}$ values for $\mathrm{Cu}\left(\mathrm{NO}_{3}\right)_{2}$ and its complexes decreases in the order: $\mathrm{Cu}\left(\mathrm{NO}_{3}\right)_{2}>\mathrm{Cu}$-sac-bp $>\mathrm{Cu}$-sac $>\mathrm{Cu}$-sac-phen $>\mathrm{Cu}$-sac-py.

The $k_{f}$ valuves were calculated from $\mathrm{CV}$ data for different systems from the theory developed by Nichloson and Shain $^{25}$, as described in a review by Brown and Sandifer ${ }^{26}$.

\section{References}

1. Swaminathan M. (1991). Advanced Text Book on Food and Nutrition (Volume 2, $2^{\text {nd }}$ edition). pp.246. Bangalore Publishing, India.

2. Singh B.K., Bhojak N., Parashuram M. \& Bhagwan S.G. (2008). Copper(II) complexes with bioactive carboxyamide: synthesis, characterization and biological activity. Spectrochimica Acta Part A: Molecular and Biomolecular Spectroscopy 70(4): 758-765.

3. Jovanovsky G., Naumov P. \& Grupc`e O. (1998). Structural study of monoaquabis (pyridine)bis(saccharinato) copper(II). European Journal of Solid State and Inorganic Chemistry 35(3): 231-242.

4. Li J., Zhang Y., Lin W., Liu S. \& Huang J. (1992). Crystal structure and spectra studies of $\left[\mathrm{Co}(\mathrm{Im})_{4}\left(\mathrm{H}_{2} \mathrm{O}\right)_{2}\right](\mathrm{HSac})_{2}$ complex. Polyhedron 11: 419-422.

5. Zhang Y., Li J., Lin W., Liu S. \& Huang J. (1992). Synthesis, crystal structure, and spectral studies of the complex $\left[\mathrm{Ni}\left(\mathrm{C}_{3} \mathrm{H}_{4} \mathrm{~N}_{2}\right)_{4}\left(\mathrm{H}_{2} \mathrm{O}\right)_{2}\right]-\left(\mathrm{C}_{6} \mathrm{H}_{4} \mathrm{COSO}_{2} \mathrm{~N}\right)_{2}$. Journal of Crystallographic and Spectroscopic Research 22(3): 433-438.

6. Liu S., Huang J., Li J. \& Lin W. (1991). Structure of a copper complex containing saccharin and imidazole: $\left[\mathrm{Cu}_{2}\left(\mathrm{C}_{6} \mathrm{H}_{4} \mathrm{COSO}_{2} \mathrm{~N}\right)_{4}\left(\mathrm{C}_{3} \mathrm{H}_{4} \mathrm{~N}_{2}\right)_{4}\right]$. Acta Crystallographica C 47: 41-43.
7. Li J., Ke Y., Wang Q. \& Wu X. (1997). Synthesis, crystal and molecular structure of $\mathrm{Cd}_{2}(\mathrm{sacch})_{4}(\mathrm{Im})_{4}$. Crystal Research and Technology 32(3): 481-483.

8. Hergold-Brundic A., Grupc e O. \& Jovanovski G. (1991). Structure of bis(2,2'-bipyridyl)(saccharinato- $N$ )copper(II) saccharinate dehydrate Acta Crystallographica $C$ 47: 2659-2660.

9. Li J., Chen H., Wu Q. \& Wu X. (1993). Structure of a manganese (II) complex containing saccharin and 1,10phenanthroline: $\left[\mathrm{Mn}(\mathrm{Sacch})_{2}(\mathrm{o}-\mathrm{Phen})_{2}\left(\mathrm{H}_{2} \mathrm{O}\right)_{2}\right] \mathrm{H}_{2} \mathrm{O}$. Crystal Research and Technology 28(2): 181-186.

10. Huang L., Wang K. Z., Huang C. H., Li F. Y. \& Huang Y. (2001). Bright red electroluminescent devices using novel second-ligand-contained europium complexes as emitting layers. Journal of Material Chemistry 11: 790-793.

11. Sano T., Fujita M., Fujii T., Hamada Y., Shibata K. \& Kuroki K. (1995). Novel europium complex for electroluminescent devices with sharp red emission. Japanese Journal of Applied Physics 34(4A): 1883-1887.

12. Liu L., Li W.L., Hong Z.R., Peng J.B., Liu X.Y., Liang C. J., Liu Z.B., Yu J.Q. \& Zhao D.X. ( 1997). Europium complexes as emitters in organic electroluminescent devices. Synthetic Metals 91: 267-269.

13. Shaikh A.A., Begum M., Khan A.H. \& Ehsan M.Q. (2006). Cyclic voltammetric studies of the redox behavior of iron(III)-vitamin B6 complex at carbon paste electrode. Russian Journal of Electrochemistry 42(6): 620-625.

14. Robinson R.A. \& Stokes R.H. (1968) Electrolyte Solutions, ( $2^{\text {nd }}$ edition.) pp. 67-70, Butterworths, London.

15. Romman U.K.R., Malik K.M.A. \& Haider S.Z. (1999). Synthesis, characterization and properties of some saccharine complexes containing 1,10-phenanthroline as secondary ligand.00 Journal of Bangladesh Chemical Society 6(1): 43-50.

16. Haider S.Z., Malik K.M.A. \& Ahmed K.A.J. (1981). Synthesis characterization and properties of some saccharine complexes containing 2, 2'-bipyridil as secondary ligand. Journal of Bangladesh Academy of Science 23(2): 155-162.

17. Wopshall R.H. \& Shain I. (1967). Effects of adsorption of electroactive species in stationary electrode polarography. Analytical Chemistry 39: 1514-1527.

18. Mascus M., Pariente F., Wu Q., Toffanin A., Shapleigh J. P. \& Abruna H. D. (1996). Electrocatalytic reduction of nitric oxide at electrodes modified with electropolymerized films of $[\mathrm{Cr}(\mathrm{v}$-tpy)2]3+ and their application to cellular NO determinations. Analytical Chemistry 68: 3128-3134.

19. Salimi A. \& Ghadermazi M. (2002). Electrocatalytic reduction of dioxygen on a glassy carbon electrode modified with adsorbed cobaloxime complex. Analytical Sciences 17(10):1165-1170.

20. Rossiter B. W. \& Hamilton J. F. (1986). Physical Methods of Chemistry, Electrochemical Methods. Chapter 1, volume.2, John Willey and Sons Inc., London.

21. Bard A.J. \& Faulkner L.R. (1980). Electrochemical Methods, Fundamentals and Applications. pp. 199-236, John Wiley and Sons Inc., New York. 
22. Zhang J. \& Anson F.C. (1992). Voltammetry and in-situ Fourier transform IR spectroscopy of two anthraquinone disulfonates adsorbed on graphite electrodes. Journal of Electroanalytical Chemistry 331: 945-957.

23. Wopschall R.H. \& Shain I. (1967). Adsorption effects in stationary electrode polarography with a chemical reaction following charge transfer. Analytical Chemistry 39: 15351542.

24. Ye J.S., Wen Y., Zhang W.D., Leong M. G., Xu G.Q. \& Sheu F.S. (2003). Selective voltammetric detection of uric acid in the presence of ascorbic acid at well-aligned carbon nanotube electrode Electroanalysis 21: 1693-1698.

25. Nicholson R.S.\& Shain, I. (1964). Theory of stationary electrode polarography: single scan and cyclic methods applied to reversible, irreversible, and kinetic systems. Analytical Chemistry 36:706-723.

26. Brown E.R. \& Sandifier J.R. (1986), Physical Methods of Chemistry, $2^{\text {nd }}$ edition, volume 2. pp.321-324, John Willey and Sons Inc., New York. 